\title{
Calcium bioavailability of raw and extruded amaranth grains
}

\author{
Biodisponibilidade do cálcio do grão de amaranto antes e após extrusão
}

\author{
Tania Aparecida FERREIRA ${ }^{1}$, José Alfredo Gomes ARÊAS ${ }^{2, *}$
}

\begin{abstract}
Calcium bioavailability of raw and extruded amaranth grains was assessed in a biological assay in rats. Rats were fed for 28 days on diets in which raw or extruded amaranth was the only calcium source, compared to a control diet with calcium carbonate. Calcium and phosphorous levels were determined in the rats' serum during the experimental period and in the bones at the end of the experiment. Amaranth extrusion increased its calcium bioavailability, assessed by tibia and femur weights and calcium and phosphorous content of the bones. Apparent calcium absorption index, the force needed to break the bones and bone densitometry of both extruded and raw amaranth were the same, though different from the control group. The results show that amaranth can be a complementary source of dietary calcium the bioavailability of which is favorably modified by the extrusion process.
\end{abstract}

Keywords: novel foods; densitometry; calcium absorption; rats; antinutritional factors.

\section{Resumo}

A biodisponibilidade do cálcio de amaranto antes e após extrusão foi avaliada em ensaio biológico. Ratos, alimentados por 28 dias com dietas em que amaranto, antes ou após extrusão, era a única fonte de cálcio da dieta, foram comparados com animais em dieta controle com teor próximo de cálcio, oferecido na forma de carbonato de cálcio. Cálcio e fósforo foram determinados no soro dos animais durante o período experimental e nos ossos, ao final do experimento. A extrusão do amaranto aumentou a biodisponibilidade do seu cálcio, quando avaliado pelo conteúdo de cálcio e fósforo da tíbia e fêmur dos animais, bem como pelo peso desses ossos. O índice aparente de absorção de cálcio, força para romper os ossos e densidade óssea foram iguais antes e após a extrusão do amaranto e diferentes do grupo controle. Os resultados mostram que o amaranto pode ser uma fonte complementar de cálcio e que sua biodisponibilidade aumenta com o processo de extrusão. Palavras-chave: novos alimentos; densitometria; absorção de cálcio; ratos; fatores antinutricionais.

\section{Introduction}

The Andean crop amaranth (Amaranth caudatus L., and other species: A. cruentus, A. hypocondriacus), is a pseudo cereal that during the last twenty years has been the focus of attention in many scientific studies, chiefly on account of its nutritional, functional, agricultural and technological potential (BERGHOFER; SCHOENLECHNER, 2002; LEHMANN, 1996). Calcium and iron contents vary among cultivars of this crop from 1300 to $2136 \mathrm{ppm}$ in dry basis, (average $1870 \mathrm{ppm}$ ) and from $72.2 \mathrm{ppm}$ to $116 \mathrm{ppm}$, (average $101 \mathrm{ppm}$ ), respectively (BECKER et al., 1981). This represents six times more calcium and four times more iron than that observed in wheat grains. Amaranth is therefore a potential raw material to be introduced in human diet as a new iron and calcium source.

Amaranth is not part of modern food consumption habits. Thus, a convenience food based on amaranth, similar to the ones available to consumers, was produced by extrusion cooking (CHÁVEZ-JÁUREGUI; SILVA; ARÊAS, 2000). This new product presented high commercial potential as a functional food, as it is able to reduce blood cholesterol (PLATE; ARÊAS, 2002), and provide high quality protein, high fiber and high calcium contents for human diet. Consumption of a $30 \mathrm{~g}$ portion of this product would meet practically $100 \%$ of the RDA for calcium for 2-5 year old children (INSTITUTE OF MEDICINE, 2002; KREBS, 2001).

Calcium deficiency is an important nutritional problem and its bioavailability is a fundamental aspect for human diet. The objective of this work was therefore to determine the in vivo calcium bioavailability of raw and extruded amaranth in rats after 28 days feeding.

\section{Materials and methods}

\subsection{Amaranth}

Amaranth (Amaranthus caudatus L.) CAC-43A, Oscar Blanco variety, from the germ plasma bank of the Centro de Investigación en Cultivos Andinos (CICA) of the National University of San Antonio Abad del Cusco-Perú, was used in this study.

The amaranth grain was sieved and milled in a hammer mill (Marconi, São Paulo, Brazil). The flour thus produced was defatted with n-hexane for 12 hours in a Soxhlet apparatus (residual lipid $<1 \%$ ), and water was added to the desired moisture and sealed in polyethylene bags for 48 hours at $5{ }^{\circ} \mathrm{C}$.

Recebido para publicação em 20/8/2008

Aceito para publicação em 26/6/2009 (003808)

${ }^{1}$ Faculdade de Nutrição, Universidade Federal de Goiás, Rua 227, Qd. 68, s/no., Setor Leste Universitário, CP 131, CEP 74605-080, Goiânia - GO, Brasil

${ }^{2}$ Departamento de Nutrição, Faculdade de Saúde Pública, Universidade de São Paulo - USP, Av. Dr. Arnaldo, 715, CEP 01246-904, São Paulo - SP, Brasil, E-mail: jagareas@usp.br

${ }^{*}$ A quem a correspondência deve ser enviada 


\subsection{Extrusion}

Extrusion was performed with $15 \%$ feed moisture at $150{ }^{\circ} \mathrm{C}$ in a laboratory scale single screw extruder of $20 \mathrm{~mm}$ diameter and a length to diameter ratio equal to 20 . The extruder was divided into three independent heating zones. Screw compression ratio was 4:1 and screw speed $200 \mathrm{rpm}$. Die diameter was $3 \mathrm{~mm}$ and feeding was performed by gravity through a hopper (CHÁVEZ-JÁUREGUI; SILVA; ARÊAS, 2000). After extrusion, the product was milled to produce flour that had its dietary fiber, phytates and tannins, determined.

\section{Proximate composition}

Proximate composition was determined by conventional methods: drying to constant weight at $105^{\circ} \mathrm{C}$ for moisture, calcination to constant weight at $550^{\circ} \mathrm{C}$ for ash, defatting in glass Soxhlet apparatus with $\mathrm{n}$-hexane for lipids, micro-kjeldahl for organic nitrogen $(\mathrm{N} \times 6.25=$ protein $)($ INSTITUTO ADOLFO LUTZ, 1985).

\section{Analysis of tannins}

The tannins were extracted from $200 \mathrm{mg}$ sample by $10 \mathrm{~mL}$ methanol for 20 minutes shaking followed by centrifugation at $6.000 \times \mathrm{g}$ for 15 minutes. Tannins were determined in the supernatant by the vanilla method (PRICE; VAN SCOYOE; BUTLER, 1978) using cathechin as standard and the results were calculated as cathechin equivalents.

\section{Analysis of phytates}

Phytates were analyzed by ferric chloride precipitation of the phytates from water extracts of the samples, separation and washing of this precipitate by centrifugation $(6.000 \times \mathrm{g})$ (THOMPSON; ERDMAN, 1982) and phosphorous determination after hydrolysis (FISKE; SUBBAROW, 1925). A conversion factor of 3.5 was used to transform phosphorous contents in phytates (phosphorous corresponds to $28.2 \%$ in mass of phytates).

\section{Dietary fiber determination}

Soluble and insoluble fiber contents were determined by the enzymatic method as described (PROSKY et al., 1988). Enzymes used were amyloglucosidase A-9913, thermo resistant amylase A-3306 and protease P-3910, all provided by Sigma Aldrich Fine Chemicals (USA).

\section{Calcium determination}

Calcium was determined in diets and femurs. Calcium analysis was carried out after wet digestion of the samples with nitric acid and 30\% hydrogen peroxide (5:1 v/v) mixture at $150{ }^{\circ} \mathrm{C}$, by flame ionization atomic absorption spectrometry (Perkin-Elmer, model GBC932AA, USA), using a specific hollow cathode lamp at $422.7 \mathrm{~nm}$ against a calibration curve (PRICE; VAN SCOYOE; BUTLER, 1978; MARSHALL, 1987). Flame was produced by acetylene/air mixture and all other conditions were optimized for this analysis.

\section{Phosphorous determination}

Phosphorous was determined in the same samples for calcium analyses, by conventional colorimetric method (FISKE; SUBBAROW, 1925) in a different aliquot of the same solutions used for calcium determination.

\section{Biological experiments for calcium bioavailability}

The biological assay followed the guidelines of the 'Colégio Brasileiro de Experimentação Animal' (Brazilian College for Animal Experiments) under supervision of a Veterinary professional and it was approved by the Goiás Federal University. The experiment was carried out using a completely randomized block design with 32 newly-weaned rats, (Rattus norvergicus, var. Wistar), in four groups of eight animals each, kept in individual cages. The animals were fed for 28 days on the experimental and control diets with water provided ad libitum. They were kept in individual cages in an animal house with air conditioning at $23{ }^{\circ} \mathrm{C}$ and equal daily light and dark periods of 12 hours. At the end of the experimental period, all animals were killed by guillotine by a Veterinary professional. The feces were collected daily in the last three days of experiment, dried at $105^{\circ} \mathrm{C}$, weighed and stored at $20{ }^{\circ} \mathrm{C}$ for further analysis. A "doubledecker" cage was designed to avoid urine contamination of the collected feces. It consisted of two floors made of distinct mesh size nets that allowed feces to pass through the first one, where the animal was kept, whereas they were retained in a second one that was removed after the three-day collection period. Animal's urine passed through both nets and was discarded. Before killing the animals fasted for 12 hours, the blood was collected, centrifuged at $3.000 \times \mathrm{g}$ for 20 minutes, and the serum stored at $-20{ }^{\circ} \mathrm{C}$ for further analysis. Right and left femurs and left tibias were removed from the animals, cleaned from adherent tissue and stored either in foiled sheet at $-20{ }^{\circ} \mathrm{C}$, for breaking tests, or in $70 \%$ ethanol solution at $10^{\circ} \mathrm{C}$, for bone densitometry and calcium determination.

\section{Diets}

Calcium free saline mixture was prepared by removing calcium carbonate and used to produce the experimental diets where the only calcium and protein (at 10\% level) source were the raw and extruded amaranth grains. Calcium content of this diet was $0.13 \mathrm{~g}$ per $100 \mathrm{~g}$ of diet. To keep an experimental diet with the same amount of nutrients, as compared to the control, the amount of protein, carbohydrate and lipids from raw and extruded amaranth were taken into account for its manufacturing. The control diet was then prepared based on the semi-purified diet AIN 93-G, according to National Research Council (NATIONAL RESEARCH COUNCIL, 1993), with casein as protein source and calcium carbonate as the calcium source at the same concentration of the experimental diets, $0.13 \mathrm{~g}$ per $100 \mathrm{~g}$. Calcium to phosphorous ratio was around 0.375 in the control diet. The amount of ingredients used for the confection of all diets is presented in Table 1. Proximal analysis of these diets showed that there was little difference among them, in terms of macro nutrient composition. Ash in the amaranth diets were higher than the control one as the latter was kept as recommended by AIN-93G (Table 2). 


\section{Bone densitometry}

Each right femur was rinsed with physiological solution $(0.9 \% \mathrm{NaCl})$, dried with gauze and immersed in $50 \mathrm{~mL}$ of distilled water and kept in $8 \times 4 \mathrm{~cm}$ acrylic box that guaranteed the same depth in all measurements with the double bundle X-ray. A bone densitometer (model Hologic QDR2000 plus, Lunar Corporation, Madison, WI, USA) was used for all measurements. They were carried out by dual energy X-ray absorption (DEXA) adjusting the high resolution required for

Table 1. Ingredient composition of diets.

\begin{tabular}{lccc}
\hline \multicolumn{1}{c}{ Ingredients } & $\begin{array}{c}\text { Extruded } \\
\text { amaranth } \\
(\%)\end{array}$ & $\begin{array}{c}\text { Raw } \\
\text { amaranth } \\
(\%)\end{array}$ & $\begin{array}{c}\text { Control }^{1} \\
(\%)\end{array}$ \\
\hline Choline & 0.25 & 0.25 & 0.25 \\
Bitartrate & & & \\
L-Cystine & 0.30 & 0.30 & 0.30 \\
Vitamin mix $^{3}$ & 1.0 & 1.0 & 1.0 \\
CaCO $_{3}$ & - & - & 0.35 \\
Cellulose & 3.3 & 3.3 & 5.0 \\
Mineral mix & 3.5 & 3.5 & 3.5 \\
Soybean oil & 6.4 & 6.4 & 7.0 \\
Protein source & 77.5 & 77.5 & 12.7 \\
Corn starch & 7.7 & 7.7 & 70.7 \\
Total & 100.0 & 100.0 & 100.0 \\
\hline
\end{tabular}

${ }^{1}$ Casein diet with $0.13 \mathrm{~g}$ Ca.100 g $\mathrm{g}^{-1}$ of diet. ${ }^{2} 41.4 \%$ choline. ${ }^{3}$ Vitamin mix AIN-93G (g.kg-1 mixture): nicotinic acid, 3 g. $\mathrm{kg}^{-1}$; pantothenate, 1.6 g. $\mathrm{kg}^{-1}$; pyridoxine, $0.7 \mathrm{~g} . \mathrm{kg}^{-1}$; thiamine, $0.6 \mathrm{~g} . \mathrm{kg}^{-1}$; riboflavin, $0.6 \mathrm{~g} . \mathrm{kg}^{-1}$; folic acid, $0.2 \mathrm{~g}$. $\mathrm{kg}^{-1}$; D-biotin, $0.020 \mathrm{~g}^{\mathrm{kg}} \mathrm{kg}^{-1}$;

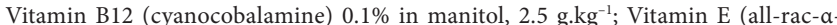
tocoferil acetate), $7500 \mathrm{UI.g}{ }^{-1}$; Vitamin A (all-trans retinil palmitate), $0.400 \mathrm{~g}^{\mathrm{kg}} \mathrm{kg}^{-1}$, Vitamin D3 (cholecalciferol) $1000 \mathrm{UI} . \mathrm{kg}^{-1}$; Vitamin K, $0.075 \mathrm{~g} . \mathrm{kg}^{-1} .{ }^{4}$ Mineral mix AIN-93G (g. kg ${ }^{-1}$ mixture): calcium carbonate, anhydrous, $40.04 \% \mathrm{Ca}, 357 \mathrm{~g}^{\mathrm{kg}} \mathrm{kg}^{-1}$; potassium phosphate, monobasic, $22.76 \% \mathrm{P}$ and $28.73 \% \mathrm{~K}, 96 \mathrm{~g} . \mathrm{kg}^{-1}$; potassium citrate, tri-potassium, monohydrate, $36.16 \% \mathrm{~K}, 70.78$; sodium chloride, $39.34 \% \mathrm{Na}, 60.66 \% \mathrm{Cl}$, 74 g.kg-1; potassium sulphate, $44.87 \% \mathrm{~K}$ e $18.39 \% \mathrm{~S}, 46.60 \mathrm{~g} . \mathrm{kg}^{-1}$; magnesium oxide,

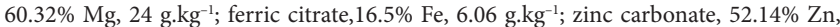
$1.65 \mathrm{k}^{\mathrm{kg}}{ }^{-1}$; manganese carbonate, $47.79 \% \mathrm{Mn}, 0.63 \mathrm{~g} . \mathrm{kg}^{-1}$; cupric carbonate, $57.47 \% \mathrm{Cu}$, $0.30 \mathrm{~g} . \mathrm{kg}^{-1}$; potassium iodate, $59.3 \% \mathrm{I}, 0.01 \mathrm{~g}^{\mathrm{kg}} \mathrm{kg}^{-1}$; sodium selenate, anhydrous, $41.79 \%$ Se, 0.01025 g.kg-1; ammonium paramolybdate, 4 hydrate, $54.34 \%$ Mo, 0.00795 g.kg ${ }^{-1}$; sodium meta-silicate, 9 hydrate, $9.88 \% \mathrm{Si}, 1.45 \mathrm{~g}^{\mathrm{kg}} \mathrm{kg}^{-1}$; chromium potassium sulphate,

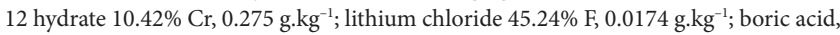
$7.5 \%$ B, 0.0815 g. $\mathrm{kg}^{-1}$; sodium fluoride $45.24 \%$ F, 0.0635 g. $\mathrm{kg}^{-1}$; nickel carbonate, $45 \%$ $\mathrm{Ni}, 0.0318 \mathrm{~g} . \mathrm{kg}^{-1}$; ammonium vanadate, $43.55 \% \mathrm{~V}, 0.0066 \mathrm{~g}^{\mathrm{kg}}{ }^{-1}$; and powdered sucrose, 221.03 g.kg-1. ${ }^{5}$ Target protein concentration: $10 \%$.

Table 2. Proximate per cent composition, calcium and phosphorous contents of diets (w.b).

\begin{tabular}{lccc}
\hline & Extruded am. & Raw am. & Control \\
\hline Moisture $\left(\mathrm{g} .100 \mathrm{~g} \mathrm{~g}^{-1}\right)$ & $6.7 \pm 0.3$ & $6.8 \pm 0.2$ & $6.4 \pm 0.3$ \\
Ash $\left(\mathrm{g} .100 \mathrm{~g}^{-1}\right)$ & $3.3 \pm 0.0$ & $3.3 \pm 0.0$ & $1.8 \pm 0.0$ \\
Protein $\left(\mathrm{g} .100 \mathrm{~g} \mathrm{~g}^{-1}\right)$ & $10.8 \pm 0.03$ & $10.4 \pm 0.21$ & $11.0 \pm 0.28$ \\
Lipids $\left(\mathrm{g} .100 \mathrm{~g}^{-1}\right)$ & $7.9 \pm 0.1$ & $8.1 \pm 0.4$ & $8.0 \pm 0.2$ \\
Carbohydrate by & 71.3 & 71.4 & 71.7 \\
difference $\left({\left.\mathrm{g} .100 \mathrm{~g}^{-1}\right)}\right.$ & & & \\
Ca $\left(\mathrm{mg} 100 \mathrm{~g}^{-1}\right)$ & $133.2 \pm 14$ & $105.4 \pm 13$ & $133.1 \pm 21$ \\
$\mathrm{P}\left(\mathrm{mg} .100 \mathrm{~g} \mathrm{~g}^{-1}\right)$ & $1295 \pm 180$ & $1227 \pm 238$ & $682 \pm 97$ \\
\hline
\end{tabular}

Extruded Am.: extruded amaranth at $150{ }^{\circ} \mathrm{C}$ and $15 \%$ moisture content; Raw Am.: raw amaranth; Control: Casein diet with $0.13 \mathrm{~g} \mathrm{Ca} .100 \mathrm{~g}^{-1}$ of diet; w.b: wet base. the small bone masses by using appropriate computer software. Bone mineral content (BMC), expressed in grams, and bone area, expressed in $\mathrm{cm}^{2}$ were determined, and bone mineral density (BMD) was calculated as the ratio $\mathrm{BMC} /$ area and expressed in ${\mathrm{g} . \mathrm{cm}^{-2}}^{-}$. Two energy levels (38 and $70 \mathrm{keV}$ ) were used to distinguish mineralized from soft tissue and correctly reconstruct the final image properly adjusted in contrast and brightness (Figure 1). A reference with known density was used as standard and both bone area and density were calculated (NRC, 1993).

Coefficient of variation between measurements was below $0.5 \%$ in the same sample and below $5 \%$ in 30 samples for bone density determinations.

\section{Tibia shearing force}

Tibias were dried overnight ( 12 hours) at $105^{\circ} \mathrm{C}$ in an oven, and submitted to a complete breaking in three different points, using a Warner-Bratzler cell in a Food Texturometer (TAXT2i, TA Instruments, UK). Cross head speed was $2 \mathrm{~mm} . \mathrm{s}^{-1}$, and maximum force for completely shear the bone was recorded (OKANO et al., 1994).

\section{Biochemical analysis}

Serum levels of calcium, phosphorous, alkaline phosphatase, and albumin were determined by an automated biochemical analyzer (Mod. Mega - Merck Diagnostic). Samples were collected from the animals in the last three days of experiment as described before.

Rat femur from the casein control

Rat femur from the casein control adjusted in contrast and bright

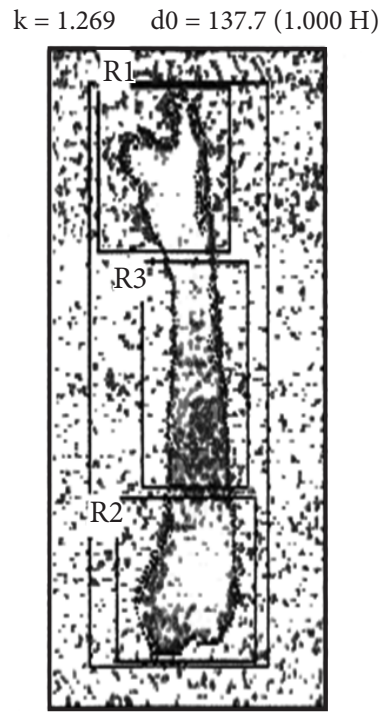

Hologic QDR-2000 Plus (S/N 2614) Subregion Hi-Res v4.71

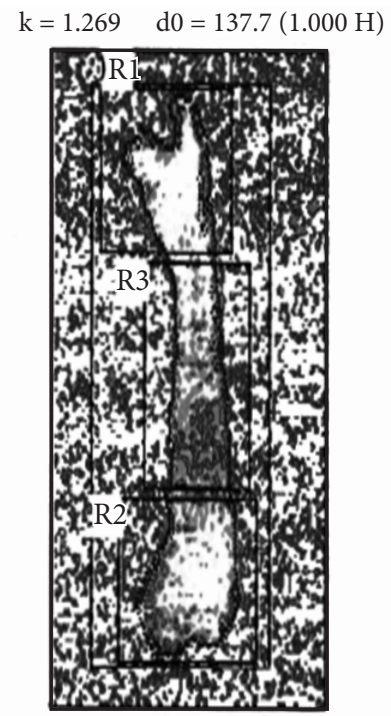

Hologic QDR-2000 Plus (S/N 2614) Subregion Hi-Res v4.71
Figure 1. Digitized image in different contrast and bright. 


\section{Apparent absorption index}

The apparent absorption index was calculated for calcium as the percentage of the amount of calcium absorbed in relation to the amount ingested in the last three days of experiment. The amount absorbed was calculated by the subtraction of the intake mineral amount and the excreted mineral amount in the feces in the last three days of experiment (BRINK et al., 1982, GOEL; ORAIKUL; BASU, 1996).

\section{Statistical analysis}

Statistical analyses applied were ANOVA with a fixed factor and the Tukey test to compare means. Significance levels were considered for $\mathrm{p} \leq 0.05$ and all calculations were performed using the 'Statistical Analysis System' - SAS - software (version 6, 1989) (STATISTICAL, 1989).

\section{Results and discussion}

Diets were formulated as indicated in Table 1. Proximate composition of these diets is presented in Table 2. The tannin, phytate and fiber contents are presented in Table 3. Tannin levels observed for the raw and extruded amaranth were low and should not have any impact on the bioavailability of calcium. Phytates level encountered were also small as compared to other foods (millets, wheat and triticale, 200, 170 and $190 \mathrm{mg}$ phytate. $100 \mathrm{~g}^{-1}$ respectively, (ARELLANO et al., 1992) (Table 3). Fiber contents of raw and extruded amaranth grains showed that the extrusion process reduced the original soluble and insoluble fiber contents.

Diet consumption was statistically different in all groups. Animals from the casein group consumed more diet followed by the extruded amaranth and the raw amaranth groups (results of the three last days) (Table 6). Similar to other studies, the consumption of the extruded amaranth diet was greater than the consumption of the raw amaranth diet. The raw amaranth diet did not promote animal growth as did the control casein and extruded amaranth diet as described previously by Ferreira and Arêas (2004).

Mineral content of femur, expressed by the amount of calcium and phosphorous present, was the same as the control in the animals fed on the extruded amaranth diet but it was smaller than the control for the animals fed on raw amaranth

Table 3. Tannins, Phytates and dietary fibers of extruded and raw amaranth (d.b). ${ }^{1}$

\begin{tabular}{|c|c|c|c|}
\hline & & Extruded am. ${ }^{2}$ & Raw amaranth \\
\hline \multirow{4}{*}{$\begin{array}{l}\text { Total dietary } \\
\text { fiber }\left(\mathrm{g} .100 \mathrm{~g}^{-1}\right)\end{array}$} & $\begin{array}{c}\text { Tannins } \\
\left(\mathrm{mg} \mathrm{CE} .100 \mathrm{~g}^{-1}\right)^{3}\end{array}$ & $1284 \pm 0.52^{\mathrm{a}}$ & $1305 \pm 0.23^{\mathrm{a}}$ \\
\hline & $\begin{array}{c}\text { phytate } \\
\left(\mathrm{mg} .100 \mathrm{~g}^{-1}\right)\end{array}$ & $82.0 \pm 010^{\mathrm{a}}$ & $82.0 \pm 0.13^{\mathrm{a}}$ \\
\hline & Insoluble & $3.26 \pm 0.16^{\mathrm{b}}$ & $4.97 \pm 0.47^{\mathrm{a}}$ \\
\hline & Soluble & $3.74 \pm 0.42^{\mathrm{a}}$ & $5.32 \pm 0.20^{\mathrm{a}}$ \\
\hline
\end{tabular}

diet (Table 4). The force necessary to completely break the animal femurs indicated no significant difference between raw and extruded amaranth. The bones from the animals of control group diet presented higher breaking resistance than the experimental ones (Table 4). Calcium and phosphorous intake and excretion in feces were determined in the last three days before sacrificing the animals and the results are displayed in Table 6.

Digestibility of amaranth protein was carried out in another study and ranged from 88.0 to $89.6 \%$. Protein efficiency ratio (PER) observed was comparable to that of casein, indicating the high quality of amaranth protein (FERREIRA; AREAS, 2004).

Since amaranth is a phosphorus source, this mineral was provided by amaranth as was calcium and protein. Protein increases urinary excretion of calcium. Every gram of metabolized protein increases the levels of urinary calcium in about $1.75 \mathrm{mg}$. However, the correct and balanced amount of calcium phosphorous and protein of the experimental design of the present work provided a homeostatic balance such that no calcium loss was expected (INSTITUTE OF MEDICINE, 2000).

Biochemical determination in the last three days of the experimental period (results not shown) revealed that the animals from experimental, raw, and extruded amaranth groups presented the same serum calcium concentration. Animals from the extruded amaranth group presented the same serum phosphorous levels as the control group, and animals from the raw amaranth group showed significantly less phosphorous than all other groups. Alkaline phosphatase activity, which reflects zinc status and bone formation (BRINK et al., 1982; GIBSON, 1990), was higher in animals in the group fed on extruded amaranth. Animals from the raw amaranth group and the control group presented lower enzyme activity.

Studies into the effect of phytates on the calcium absorption in rats, by using techniques of isotopic markers and detection of calcium content in femur or carcasses, (CHURELLA, 1989; HEANEY; WEAVER, 1990) showed no effect of the phytate presence on calcium absorption by the rats. Change in the pattern of dietary fiber composition by extrusion is observed in several distinct foods (VARO; LAINE; KOIVISTOINEN, 1983; MERCIER, 1993; GOURGUE et al., 1994). Food extrusion was reported as increasing total dietary fiber in severe or moderate extrusion conditions, by increasing resistant starch fraction and through Maillard reaction products, modifying the soluble to insoluble dietary fiber ratio (TOVAR; BJÖRCK; ASP, 1989;

Table 4. Calcium and phosphorous content from the animals' femur and force (kgf) to completely break left tibia.

\begin{tabular}{lccc}
\hline & Extruded Am. & Raw Am. & Control \\
\hline Ca femur $\left.\left(\mathrm{mg}^{-1}\right)^{-1}\right)^{1}$ & $133.4 \pm 15.8^{\mathrm{b}}$ & $81.0 \pm 21.7^{\mathrm{c}}$ & $138.9 \pm 22.4^{\mathrm{b}}$ \\
P femur $\left(\mathrm{mg} \cdot \mathrm{g}^{-1}\right)^{1}$ & $100.3 \pm 6.15^{\mathrm{cb}}$ & $89.0 \pm 4.12^{\mathrm{c}}$ & $108.1 \pm 16.54^{\mathrm{b}}$ \\
Force to break tibia (kgf) & $7.33 \pm 1.3^{\mathrm{c}}$ & $7.81 \pm 2.08^{\mathrm{c}}$ & $13.7 \pm 2.77^{\mathrm{b}}$ \\
\hline
\end{tabular}

Extruded Am.: extruded amaranth at $150{ }^{\circ} \mathrm{C}$ and $15 \%$ moisture content; Raw Am.: raw amaranth; Control: Casein diet with $0.13 \mathrm{gCa} .100 \mathrm{~g} \mathrm{~g}^{-1}$; w.b = wet base. ${ }^{*}$ Different letters in the same line, indicate significant difference between averages (Tukey, $\mathrm{p} \leq 0.05$ ). ${ }^{1}$ Average values for right and left femur. 
ASP; BJÖRCK, 1984; CHAMP, 1992; WANG; KLOPFENSTEIN, PONTE, 1993; MONGEAU; BRESSARD, 1995). Fiber content as phytates, however, seems not to influence calcium absorption (HEANEY; WEAVER, 1990) given that oxalate is the only food component that could affect calcium absorption in extruded amaranth. Extrusion also increases iron bioavailability and preserves protein nutritional value (PINTO; COLLI; ARÊAS, 1997, POLTRONIERI; ARÊAS; COLLI, 2000; CAMPOS; ARÊAS, 1993).

Despite significant differences between the observed areas by DEXA analysis for the animals from extruded and raw amaranth diet groups, bone mineral content (BMC) and bone mineral density (BMD), calculated as described in the experimental section, were not significantly different (Table 5). Animals from the control group presented higher area, higher bone mineral concentration and higher bone mineral density as compared to the experimental groups. The diets were designed to have the same calcium concentration. Thus, this reduced calcium bioavailability may be attributed to the high iron content of amaranth seeds (BECKER et al., 1981). Iron is known to interfere with calcium absorption at the intestinal level (HALLBERG et al., 1991). Therefore, the large amount of iron expected in these diets due to the high iron content of amaranth seeds may have contributed to this lower bioavailability of the experimental diets. Another point that deserves attention is the high oxalate content of amaranth seeds (GÉLINAS; SEGUIN, 2007). Oxalate can complex calcium intake, impairing its absorption, and long-term use of amaranth as part of habitual diet may increase the risk of kidney stone development. However, most of the oxalate found in amaranth is insoluble in the seed and may have little effect on calcium absorption.

Animals on the extruded amaranth diets presented significantly higher bone areas than the ones from the raw amaranth group. However, BMC and BMD were not significantly different between these two groups. These results indicate a better performance of extruded amaranth diets for bone growth as compared to the raw material. Bone mineral content calculated by DEXA analysis was not sensitive to detect differences between raw and extruded amaranth diets, as was the actual mineral analysis by chemical methods.

Animal growth in the casein control group was consistently higher than the amaranth ones, with the raw amaranth group proving to be the one with the least pronounced growth profile (Figure 2). The amount of diets ingested and the feces volume excreted were the same for all groups, except for the raw amaranth group that presented smaller diet ingestion and feces excretion (Table 6). Extrusion of amaranth provided a more palatable product that was three times more consumed by the animals than the raw amaranth as measured in the last three days of experiment. The amount of extruded amaranth diet fed in this period was not significantly different from the control one. Calcium content of the experimental diets was low and it was therefore impossible to produce a diet with amaranth as the sole source for calcium that provided the minimum calcium content for rat growth.

Calcium absorption and excretion in the last three days of the experiment is presented in Table 6, and an "apparent
Table 5. Animals' femur densitometry.

\begin{tabular}{lrrr}
\hline & Extruded Am. & Raw Am. & \multicolumn{1}{c}{ Control } \\
\hline Area $\left(\mathrm{cm}^{2}\right)$ & $1.1625 \pm 0.115^{\mathrm{b}}$ & $0.9963 \pm 0.1365^{\mathrm{c}}$ & $1.2999 \pm 0.0870^{\mathrm{a}}$ \\
BMC $(\mathrm{g})$ & $0.490 \pm 0.0100^{\mathrm{c}}$ & $0.383 \pm 0.0078^{\mathrm{c}}$ & $0.855 \pm 0.0206^{\mathrm{b}}$ \\
BMD $\left(\mathrm{g} . \mathrm{cm}^{-2}\right)$ & $0.422 \pm 0.0060^{\mathrm{c}}$ & $0.384 \pm 0.0051^{\mathrm{c}}$ & $0.658 \pm 0.0135^{\mathrm{b}}$ \\
\hline
\end{tabular}

Extruded Am.: extruded amaranth at $150{ }^{\circ} \mathrm{C}$ and $15 \%$ moisture content; Raw Am.: raw amaranth; Control: Casein diet with $0.13 \mathrm{gCa} .100 \mathrm{~g} \mathrm{~g}^{-1}$; w.b $=$ wet base. ${ }^{*}$ Different letters in the same line, indicate significant difference between averages (Tukey, $\mathrm{p} \leq 0.05$ ); $\mathrm{BMC}=$ bone mineral content; $\mathrm{BMD}=$ bone mineral density.

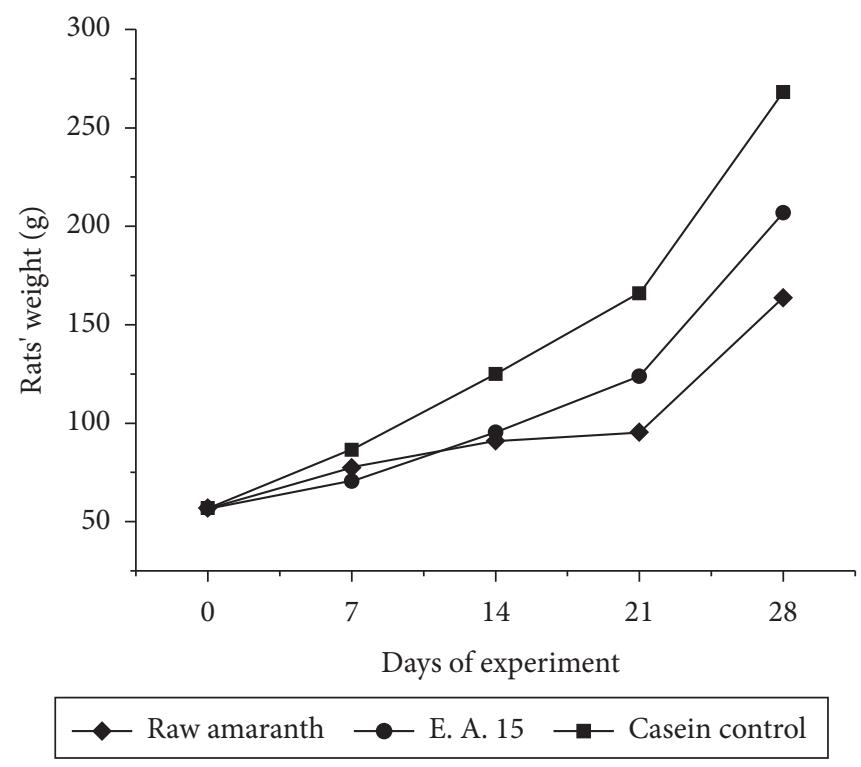

Figure 2. Animal growth during experimental period. E. A. 15: extruded amaranth at $150^{\circ} \mathrm{C}$ and $15 \%$ moisture content.

Table 6. Ca and P apparent absorption indexes.

\begin{tabular}{lccc}
\hline & Extruded am. & Raw am. & Control \\
\hline diet fed on 3 days (g) & $47.2 \pm 8.29^{\mathrm{a}}$ & $17.6 \pm 6.77^{\mathrm{b}}$ & $53.0 \pm 4.96^{\mathrm{a}}$ \\
protein fed on & $5.1 \pm 0,90^{\mathrm{b}}$ & $1.8 \pm 0,69^{\mathrm{c}}$ & $5.8 \pm 0,54^{\mathrm{a}}$ \\
3 days (g) & & & \\
faeces excreted in & $4.68 \pm 0.52^{\mathrm{a}}$ & $2.01 \pm 0.87^{\mathrm{b}}$ & $3.20 \pm 0.80^{\mathrm{ab}}$ \\
3 days (g) & & & \\
Ca fed diet (mg) & $62.8 \pm 8.66^{\mathrm{c}}$ & $18.5 \pm 8.41^{\mathrm{d}}$ & $70.4 \pm 6.6^{\mathrm{b}}$ \\
faeces excreted & $3.43 \pm 0.56^{\mathrm{b}}$ & $2.33 \pm 0.48^{\mathrm{b}}$ & $1.13 \pm 0.28^{\mathrm{b}}$ \\
Ca(mg.g $\left.{ }^{-1}\right)$ & & & \\
Ca Exc. (mg) & $16.05 \pm 2.99^{\mathrm{b}}$ & $4.68 \pm 0.48^{\mathrm{b}}$ & $3.62 \pm 0.88^{\mathrm{b}}$ \\
Ca AAbI (mg) & $74.4 \pm 4.06^{\mathrm{b}}$ & $74.7 \pm 6.59^{\mathrm{b}}$ & $94.9 \pm 1.25^{\mathrm{a}}$ \\
P fed diet (mg) & $538 \pm 101^{\mathrm{a}}$ & $198 \pm 72.4^{\mathrm{b}}$ & $90.2 \pm 8.61^{\mathrm{b}}$ \\
faeces excreted P & $7.68 \pm 3.85^{\mathrm{b}}$ & $10.4 \pm 1.75^{\mathrm{a}}$ & $2.34 \pm 0.65^{\mathrm{c}}$ \\
(mg.g $\left.{ }^{-1}\right)$ & & & \\
P Exc. (mg) & $35.9 \pm 22.54^{\mathrm{a}}$ & $20.9 \pm 11.43^{\mathrm{b}}$ & $7.49 \pm 2.7^{\mathrm{c}}$ \\
P AAbI (mg) & $93.3 \pm 3.15^{\mathrm{a}}$ & $89.4 \pm 8.8^{\mathrm{a}}$ & $91.7 \pm 2.33^{\mathrm{a}}$ \\
\hline
\end{tabular}

Extruded Am.: extruded amaranth at $150{ }^{\circ} \mathrm{C}$ and $15 \%$ moisture content; Raw Am.: raw amaranth; Control: Casein diet with $0.13 \mathrm{gCa} .100 \mathrm{~g}^{-1}$; Ca AAbI = calcium apparent absorption index; P AAbI = phosphorous apparent absorption index. ${ }^{*}$ different letters in the same line, indicate statistically significant differences between averages (Tukey, $\mathrm{p}<0.05)$.

absorption index" for calcium could then be calculated. The results obtained indicated that both raw and extruded amaranth presented between 76 to $78 \%$ of calcium absorption. It can be clearly observed that the percentage of absorbed calcium is highly dependent on calcium concentration in the diets. Higher 
amounts resulted in proportionally less absorption with more calcium excreted in the feces. Thus, although animals from the extruded and from the raw amaranth groups presented the same indices, the animals fed on extruded amaranth diet ingested twice the amount of calcium ingested by the group fed on raw amaranth, which resulted in more calcium being incorporated into bones. More studies are needed to determine the interplay between components of amaranth seeds and calcium that influence its absorption and bioavailability. Nevertheless, amaranth processed by extrusion cooking is a feasible calcium source as around of $74 \%$ of the calcium present can be absorbed and incorporated into tissues in significant amounts.

\section{Conclusions}

Amaranth extrusion increased its calcium bioavailability, assessed by tibia and femur weights and calcium and phosphorous content of the bones. The possible mechanism by which extrusion can increase calcium absorption and its bone incorporation is not yet clear. A series of chemical transformations can be produced by extrusion cooking on some calcium complexing agents such as tannins, fiber, phytates and oxalates that may explain the observed improvement in calcium bioavailability. This hypothesis needs be tested as amaranth extrusion aimed at human consumption can be optimized to reduce these antinutritional factors. These results show that this process favorably modifies amaranth seeds in such a way that it can be a complementary source of dietary calcium.

\section{Acknowledgements}

The authors are grateful to CAPES (Coordenação do Aperfeiçoamento de Pessoal de Nível Superior PICDT Program), $\mathrm{CNPq}$ (proc. 301231/83-4) for scholarships and FAPESP (proc. 98/08095-9 and 07/03896-4) for financial support.

\section{References}

ARELLANO, L. G. et al. Sabal-mexicana Mart and Sabal-Japa Wright ex Becc (Palmaceae): potential resources for animal feeding. Cuban Journal of Agricultural Science, v. 26, n. 3, p. 319-324, 1992.

ASP, N. G.; BJÖRCK, I. Nutritional properties of extruded foods. In: MERCIER, C.; LINKO, P.; HARPER, J. M. (Eds.). Extrusion Cooking. St. Paul: AACC, 1984. p. 399-433.

BECKER, R. E. et al. A compositional study of amaranth grain. Journal of Food Science, v. 46, n. 4, p. 1175-1180, 1981

BERGHOFER, E.; SCHOENLECHNER, R. Grain Amaranth. In: BELTON, P. S.; TAYLOR, J. R. N. (Eds.). Pseudocereals and Less Common Cereals. Heidelberg: Springer-Verlag, 2002. p. 219-269.

BRINK, E. J. et al. Bioavailability of magnesium and calcium from cow's milk and Soya bean beverage in rats. British Journal of Nutrition, v. 68 , n. 1, p. 271-282, 1982.

CAMPOS, M. A.; ARÊAS, J. A. G. Protein nutritional value of extrusion-cooking defatted lung flour. Food Chemistry, v. 47, n. 1, p. 61-66, 1993.

CHAMP, M. Determination of resistant starch in foods and food products: inter-laboratory study. European Journal of Clinical Nutrition, v. 46, p. S51-S62, 1992.
CHÁVEZ-JÁUREGUI, R. N.; SILVA, N. E. M. P.; ARÊAS, J. A. G.. Extrusion cooking process for amaranth (Amaranthus caudatus). Journal of Food Science, v. 66, n. 6, p. 1109-1115, 2000.

CHURELLA, V. R.; VIVIAN, V. M. Effect of phytic acid level in soy-protein based infant formulas on mineral availability in the rat. Journal of Agricultural and Food Chemistry, v. 37, n. 5, p. 1352-1357, 1989.

FISKE, D. H.; SUBBAROW, Y. The colorimetric determination of phosphorus. Journal of Biological Chemistry, v. 66, n. 2, p. 375-400, 1925.

FERREIRA, T. A. P. C.; ARÊAS, J. A. G. Protein biological value of extruded, raw and toasted amaranth grain. Pesquisa Agropecuária Tropical, v. 34, n. 1, p. 53-59, 2004.

INSTITUTE OF MEDICINE. Food and Nutrition Board: Dietary Reference Intakes (DRI) for calcium, phosphorus, magnesium, vitamin D, and fluoride. Washington: National Academy Press, 2000. $448 \mathrm{p}$

GÉLINAS, B.; SEGUIN, P. Oxalate in Grain Amaranth. Journal of Agricultural and Food Chemistry, v. 55, n. 12, p. 4789-4794, 2007.

GIBSON, R. S. Principles of Nutrition Assessment. New York: Oxford University Press, 1990. 691 p.

GOEL, V. B.; ORAIKUL, B.; BASU, T. K. Effect of dietary rhubarb stalk on the bioavailability of calcium in rats. International Journal of Food Sciences and Nutrition, v. 47, n. 2, p. 159-163, 1996.

GOURGUE, G. et al. Effect of extrusion on the hypoglycemic properties of citrus fiber: an in-vitro study. Journal of the Science of Food and Agriculture, v. 64, n. 4, p. 493-499, 1994.

HALLBERG, L. et al. Calcium-effect of different amounts on nonhemeiron and heme-iron absorption in humans. American Journal of Clinical Nutrition, v. 53, n. 1, p. 112-119, 1991.

HEANEY, R. P.; WEAVER, C. M. Calcium absorption from kale. American Journal of Clinical Nutrition, v. 51, n. 4, p. 656-657, 1990

INSTITUTO ADOLFO LUTZ - IAL. Normas Analíticas do IAL. 3 ed. São Paulo, 1985. 533 p. (v. 1)

KREBS, N. F. Bioavailability of dietary supplements and impact of physiologic state: Infants, children and adolescents. Journal of Nutrition, v. 131, p. S1351- S1354, 2001.

LEHMANN, J. W. Case history of grain amaranth as an alternative crop. Cereal Foods World, v. 41, n. 5, p. 399-411, 1996.

MARSHALL, W. D. Atomic absorption, emission and fluorescence spectrometry: principles and applications. In: PARÉ, J. R. J.; BÉLANGER, J. M. R. (Eds.). Instrumental Methods in Food Analysis. Amsterdam: Elsevier, 1987. p. 141-178.

MERCIER, C. Nutritional appraisal of extruded foods. International Journal of Food Sciences and Nutrition, v. 44, p. S45-S53, 1993.

MONGEAU, R.; BRESSARD, R. Importance of cooking temperature and pancreatic amylase indetermination of dietary fiber in dried legumes. Journal of AOAC International, v. 78, n. 4, p. 1444-1449, 1995.

OKANO, T. et al. Bioavailability of calcium from bovine bone-marrow calcium (BMCa) and calcium carbonate in vitamin $\mathrm{D}$-deficient rats. Food Chemistry, v. 51, n. 1, p. 64-67, 1994.

PINTO, T. A.; COLLI, C.; ARÊAS, J. A. G. Effect of processing on iron bioavailability of extruded bovine lung. Food Chemistry, v. 60, n. 4, p. 459-463, 1997. 
PLATE, A. Y. A.; ARÊAS, J. A. G. Cholesterol lowering effects of extruded amaranth (Amaranthus caudatus L.) in hypercholesterolemic rabbits. Food Chemistry, v. 76, n. 1, p. 1-6, 2002.

POLTRONIERI, F.; AREAS, J. A. G.; COLLI, C. Extrusion and iron bioavailability in chick pea (Cicer arietinum L.) Food Chemistry, v. 70, n. 2, p. 175-180, 2000.

PRICE, M. I.; VAN SCOYOE, S.; BUTLER, I. G. A critical evaluation of vanillin reaction as an assay for tannin in sorghum grain. Journal of Agricultural and Food Chemistry, v. 26, n. 5, p. 1214-1220, 1978.

PROSKY, L. et al. Determination of insoluble, soluble and total dietary fiber in foods and food products: inter-laboratory study. Journal of the Association of Official Analytical Chemists, v. 71, n. 5, p. 1017-1023, 1988.

REEVES, P. G. et al. AIN-93 purified diets for laboratory rodents: final report of merican Institute of Nutrition Ad Hoc Writing Committee on the Reformulation of the IN-76 A rodent diet. Journal of Nutrition, v. 123, n. 11, p. 1939-1951, 1953.

STATISTICAL ANALYSIS SYSTEM - SAS. Language and Procedures: usage. Version 6. Cary, 1989.

THOMPSON, D. B.; ERDMAN Jr., J. W. Phytic acid determination in soybean. Journal of Food Science, v. 47, n. 2, p. 513-517, 1982.

TOVAR, J.; BJÖRCK, I.; ASP, N. G. On the nutritional properties of starch and dietary fiber in cassava bread. Nutrition Reports International, v. 39, n. 6, p. 1237-1246, 1989.

VARO, P.; LAINE, R.; KOIVISTOINEN, P. Effect of heat treatment on dietary fiber: interlaboratory study. Journal of the Association of Official Analytical Chemists, v. 66, n. 4, p. 933-938, 1983.

WANG, W. M.; KLOPFENSTEIN, F. C., PONTE, J. R. J. G. Effects of twin-screw extrusion on the physical properties of dietary fiber and other components of whole wheat and wheat and wheat bran and on the baking quality of the wheat bran. Cereal Chemistry, v. 70, n. 6, p. 707-711, 1993. 